\title{
Rancangan Perangkat Pembelajaran Dengan Media TTS Pada Materi Sistem Ekskresi Manusia Kelas VIII
}

\author{
Vira Liza Putri Pratiwi ${ }^{*}$, Irdam Idrus ${ }^{1}$, Yennita ${ }^{1}$, Sri Irawati ${ }^{1}$, Neni Murniati ${ }^{1}$, Abas $^{1}$ \\ ${ }^{1}$ Program Studi S-1 Pendidikan Biologi, Fakultas Keguruan dan Ilmu Pendidikan, Universitas \\ Bengkulu, Indonesia
}

*Email: viralizapp@gmail.com

\begin{tabular}{|c|c|}
\hline Info Artikel & Abstrak \\
\hline $\begin{array}{l}\text { Diterima: } 13 \text { Oktober } 2021 \\
\text { Direvisi: } 30 \text { Oktober } 2021 \\
\text { Diterima } \\
\text { untuk diterbitkan: } 5 \text { November } \\
2021\end{array}$ & $\begin{array}{l}\text { Tujuan penelitian ini adalah untuk merancangkan perangkat } \\
\text { pembelajaran model kooperatif dengan media teka-teki silang } \\
\text { pada materi sistem ekskresi manusia untuk peserta didik kelas } \\
\text { VIII. Jenis penelitian yang digunakan adalah penelitian } \\
\text { kualitatif dan metode penelitian yang digunakan adalah }\end{array}$ \\
\hline $\begin{array}{l}\text { Keywords: } \\
\text { Media Teka-Teki Silang, } \\
\text { Model Kooperatif, } \\
\text { Perangkat Pembelajaran, } \\
\text { Rencana Pelaksanaan } \\
\text { Pembelajaran, } \\
\text { Sistem Ekskresi Manusia }\end{array}$ & $\begin{array}{l}\text { deskriptif kualitatif. Hasil penelitian yaitu deskripsi rancangan } \\
\text { perangkat pembelajaran yang terdiri dari Rencana Pelaksanaan } \\
\text { Pembelajaran (RPP). RPP menjadi pegangan yang sangat } \\
\text { membantu guru untuk melakukan proses pembelajaran secara } \\
\text { tertata. RPP yang telah dirancang menyesuaikan dengan } \\
\text { komponen-komponen RPP berdasarkan Permendikbud No. } 22 \\
\text { Tahun } 2016 \text { untuk peserta didik kelas VIII pada materi sistem } \\
\text { ekskresi manusia menggunakan model pembelajaran kooperatif } \\
\text { dengan alokasi waktu } 10 \text { JP (4 kali pertemuan) dan media teka- } \\
\text { teki silang materi sistem ekskresi manusia yang dirancang } \\
\text { untuk } 4 \text { kali pertemuan dibuat dengan menggunakan aplikasi } \\
\text { Eclipse Crossword dengan format terdiri dari halaman depan, } \\
\text { lembar identitas peserta didik, lembar pengantar dan tujuan } \\
\text { pembelajaran, lembar landasan teori dan peraturan permainan } \\
\text { teka-teki silang, lembar pertanyaan dan lembar jawaban yang } \\
\text { diisi secara horizontal dan vertikal. Perangkat pembelajaran } \\
\text { tersebut dirancang untuk digunakan pada model kooperatif } \\
\text { pada materi sistem ekskresi manusia untuk peserta didik kelas } \\
\text { VIII Sekolah Menengah Pertama (SMP). }\end{array}$ \\
\hline
\end{tabular}

(C) 2021 Universitas Bengkulu. This is an open-access article under the CC-BY license (https://creativecommons.org/licenses/by/4.0)

\section{PENDAHULUAN}

Berdasarkan Undang-Undang Nomor 20 Tahun 2003 tentang Sistem Pendidikan Nasional menyebutkan pendidikan adalah usaha sadar dan terencana untuk mewujudkan suasana belajar dan proses pembelajaran agar peserta didik secara aktif mengembangkan potensi dirinya untuk memiliki kekuatan spiritual keagamaan, pengendalian diri, kepribadian, kecerdasan, akhlak mulia, serta 
keterampilan yang diperlukan dirinya, masyarakat, bangsa, dan negara. Tujuan pendidikan nasional adalah mengembangkan kemampuan dan membentuk watak serta peradaban bangsa yang bermartabat dalam rangka mencerdaskan kehidupan bangsa, bertujuan untuk berkembangnya potensi peserta didik agar menjadi manusia yang beriman dan bertakwa kepada Tuhan Yang Maha Esa, berakhlak mulia, sehat, berilmu, cakap, kreatif, mandiri, dan menjadi warga negara yang demokratis, serta bertanggung jawab. Dalam pendidikan terjadi proses belajar mengajar, belajar adalah suatu proses yang dilakukan seseorang untuk memperoleh informasi baru dari hasil pengalamannya sendiri melalui interaksi dengan lingkungannya (Sutikno, 2009).

Pendidikan di Indonesia umumnya sebelum memulai proses pembelajaran, guru merancang perangkat pembelajaran. Perangkat pembelajaran adalah alat atau perlengkapan untuk melaksanakan proses yang memungkinkan pendidik dan peserta didik melakukan kegiatan pembelajaran (Prasetyo dkk, 2011). Perangkat pembelajaran menjadi pegangan bagi guru dalam melaksanakan pembelajaran baik di kelas, laboratorium, atau di luar kelas. Meskipun perangkat pembelajaran merupakan hal wajib bagi guru, namun berdasarkan pengalaman peneliti selama magang di suatu SMP yang terletak di Kota Bengkulu masih ada guru yang jarang menggunakan perangkat pembelajaran (silabus, Rancangan Pelaksanaan Pembelajaran (RPP), Lembar Kerja Peserta Didik (LKPD) atau Lembar Diskusi Peserta Didik (LDPD), media pembelajaran, tes evaluasi, dan instrumen lainnya secara optimal. Hal tersebut dapat menjadi faktor penghambat tercapainya tujuan pendidikan sehingga tujuan belum tercapai secara maksimal. Penggunaan perangkat pembelajaran akan berpengaruh terhadap proses pembelajaran karena melalui perangkat pembelajaran guru dapat menciptakan suasana pembelajaran menjadi lebih bervariasi.

Selain merancang perangkat pembelajaran, memilih model pembelajaran yang lebih interaktif antara guru dengan peserta didik akan membantu proses pembelajaran. Salah satu contoh model pembelajaran yang dapat digunakan yaitu model pembelajaran kooperatif. Model kooperatif merupakan pembelajaran dengan cara peserta didik belajar dan bekerja sama dalam kelompokkelompok kecil yang heterogen. Model kooperatif ini dapat membantu interaksi antar peserta didik, membantu peserta didik yang memiliki latar belakang kemampuan berbeda-beda serta setiap peserta didik akan mempunyai rasa saling memiliki terhadap apa yang menjadi pertanggung jawaban bersama (Rusman, 2012). Selain memilih model pembelajaran, perlu diperhatikan juga metode pembelajaran maupun media pembelajaran karena dapat mempengaruhi proses pembelajaran. Dalam penelitian ini, peneliti memilih menambahkan metode lain selain diskusi karena metode yang paling umum digunakan di sekolah yaitu metode diskusi. Melalui diskusi, peserta didik akan lebih aktif di dalam kelas, namun jika diskusi biasa saja terus menerus akan dianggap membosankan bagi peserta didik sehingga perlu diadakannya metode lain yang lebih menyenangkan. Salah satunya mengadakan metode permainan sehingga peserta didik dapat belajar sambil bermain. Metode permainan dapat didukung dengan media pembelajaran yang menyenangkan bagi peserta didik.

Keberhasilan pembelajaran sangat ditentukan oleh dua komponen utama, yaitu metode mengajar dan media pembelajaran. Kedua komponen ini saling berkaitan dan tidak bisa dipisahkan (Lubis, 2018). Penggunaan media pembelajaran merupakan unsur yang sangat mendukung peningkatan prestasi belajar peserta didik di sekolah, apabila hanya menggunakan model kooperatif tanpa bantuan media akan menyebabkan sebagian peserta didik yang aktif, sedangkan yang lainnya menjadi pasif. Maka dari itu, adanya media akan memberi arti penting dalam mengefektifkan proses pembelajaran sehingga tercapai tujuan pembelajaran karena dapat meningkatkan keinginan peserta didik untuk belajar dan bekerja sama dalam kelompok. Melalui penggunaan media, pembelajaran akan lebih menarik perhatian peserta didik sehingga dapat memberikan motivasi belajar. Selain itu, pembelajaran juga tidak hanya berfokus pada guru tapi berfokus pada peserta didik. Menggunakan media juga dapat membantu kondisi peserta didik yang berbeda-beda. Berdasarkan hasil penelitian Lestari (2019) menunjukkan pembelajaran yang menggunakan model Think Pair Share dengan bantuan teka-teki silang dapat meningkatkan hasil belajar peserta didik kelas VII SMP Negeri 45 Palembang pada materi sistem organisasi kehidupan. 
Maka dari itu, peneliti memilih menggunakan media teka-teki silang karena dapat membuat pembelajaran menjadi menyenangkan dan efektif. Menurut Nadimah (2018) pembelajaran yang menyenangkan menyebabkan kualitas belajar peserta didik meningkat dan berpengaruh positif terhadap kemampuan mengingat peserta didik. Penggunaan teka-teki silang mampu mencegah resiko kemunduran ingatan (Pillai dkk, 2011). Selain itu, teka-teki silang dapat digunakan sebagai alternatif pemilihan media pembelajaran IPA yang cukup mudah dilaksanakan. Melalui penggunakan media teka-teki silang, diharapkan peserta didik lebih tertarik dan termotivasi untuk belajar karena tidak menjadi bosan dibanding hanya mendengarkan materi guru dan berdiskusi kelompok saja, dapat menjadi sarana menarik untuk belajar karena rasa puas yang dirasakan peserta didik yang mampu memecahkan masalah, dapat membantu peserta didik untuk memahami dan mengingat istilah-istilah ilmiah dalam pembelajaran IPA khususnya materi sistem ekskresi manusia. Pada penelitian ini, peserta didik mengisi kotak-kotak jawaban secara mendatar dan menurun mengenai sistem ekskresi manusia, sesuai dengan pertanyaan yang telah diberikan secara berkelompok. Hal tersebut sesuai dengan pendapat Standfield (2014) yang mengemukakan pembelajaran yang menggunakan TTS dalam pengenalan kata-kata ilmiah biologi mampu meningkatkan pemahaman peserta didik dalam istilah tersebut.

\section{METODE}

Jenis penelitian yang digunakan dalam penelitian ini adalah kualitatif. Penelitian kualitatif merupakan jenis penelitian yang temuan-temuannya tidak diperoleh melalui prosedur statistik atau bentuk hitungan lainnya (Strauss \& Corbin, 2003). Metode yang digunakan dalam penelitian ini adalah metode deskriptif kualitatif. Metode deskriptif adalah suatu metode penelitian yang ditujukan untuk menggambarkan fenomena-fenomena yang ada, yang berlangsung pada saat ini atau saat yang lampau (Furchan, 2004). Dalam penelitian ini menghasilkan suatu deskripsi dari rancangan perangkat pembelajaran menggunakan model kooperatif dengan media teka-teki silang yang digunakan pada materi sistem ekskresi manusia untuk peserta didik kelas VIII.

Prosedur penelitian ini dimulai dengan langkah-langkah sebagai berikut: (a) Menelaah Kurikulum 2013 yang dilakukan berdasarkan Permendikbud No. 35 Tahun 2018, (b) Menelaah Kompetensi Dasar yang dilakukan berdasarkan Permendikbud No. 37 Tahun 2018, (c) Menelaah materi berdasarkan pengetahuan fakta, konsep, prosedur, dan metakognitif, (d) merumuskan indikator dan tujuan pembelajaran yang mengacu pada KD, (e) Menentukan model dan metode pembelajaran. Model pembelajaran yang dipilih yaitu model kooperatif. Metode yang dipilih yaitu presentasi, tanya jawab, diskusi, dan permainan, (f) Memilih media pembelajaran berupa media teka-teki silang, dan (g) Menyusun alat evaluasi dengan mempertimbangkan $\mathrm{KD}$ dan tujuan pembelajaran dengan tingkat kognitif $\mathrm{C} 1$ hingga $\mathrm{C} 4$.

\section{HASIL DAN PEMBAHASAN}

Berdasarkan hasil penelitian yaitu rancangan perangkat pembelajaran untuk model kooperatif berupa Rencana Pelaksanaan Pembelajaran (RPP) dengan media Teka-Teki Silang (TTS) pada materi sistem ekskresi manusia untuk peserta didik kelas VIII sebagai berikut:

\section{Rencana Pelaksanaan Pembelajaran (RPP)}

RPP adalah rencana yang menggambarkan prosedur dan manajemen pembelajaran untuk mencapai satu atau lebih kompetensi dasar yang diterapkan dalam standar isi dan dijabarkan dalam silabus. RPP menjadi pegangan yang sangat membantu guru untuk melakukan proses pembelajaran secara tertata. Tanpa perencanaan yang dibuat dengan baik, maka proses dan hasil akan sulit tercapai secara maksimal (Mulyasa, 2007). Berdasarkan Permendikbud No. 22 Tahun 2016, RPP dikembangkan dari silabus untuk mengarahkan kegiatan pembelajaran peserta didik dalam upaya mencapai Kompetensi Dasar (KD). Dalam penelitian ini, RPP dirancang menggunakan model pembelajaran kooperatif untuk 4 kali pertemuan menyesuaikan dengan komponen-komponen RPP berdasarkan Permendikbud No. 22 Tahun 2016 yang terdiri atas: 
Identitas Sekolah, yaitu nama satuan pendidikan

Bagian ini menunjukkan satuan pendidikan berupa nama sekolah. Dalam penelitian ini, sekolah yang dimaksud adalah Sekolah Menengah Pertama (SMP).

Identitas Mata Pelajaran Atau Tema/Subtema

Bagian ini menunjukkan mata pelajaran yang diajarkan selama proses pembelajaran. Dalam penelitian ini, mata pelajarannya yaitu Ilmu Pengetahuan Alam (IPA).

Kelas/Semester

Bagian ini menunjukkan kelas dan semester berapa yang diajarkan pada mata pelajaran tertentu. Dalam penelitian ini, kelas yang diajarkan yaitu kelas VIII (delapan) pada semester genap.

Materi Pokok

Bagian ini menunjukkan materi pokok yang diajarkan pada jadwal yang telah ditetapkan. Dalam penelitian ini, materi pokoknya yaitu sistem ekskresi manusia yang memuat pengetahuan fakta, konsep, prosedural, dan metakognitif.

Alokasi Waktu

Bagian ini menunjukkan jumlah waktu yang dibutuhkan untuk mencapai KD pada materi tertentu dengan mengacu pada silabus. Dalam penelitian ini, alokasi waktu yang dibutuhkan untuk materi sistem ekskresi manusia kelas VIII yaitu 10 JP. Menurut Permendikbud No. 35 Tahun 2018 lama belajar SMP/MTs adalah 40 menit untuk 1 jamnya. Sehingga jika dirincikan 10 JP x 40 Menit @400 menit (bisa dialokasikan menjadi 4 pertemuan) karena untuk mata pelajaran IPA di SMP memiliki waktu $5 \mathrm{JP} /$ minggu untuk 2 kali pertemuan.

Kompetensi Inti (KI)

Bagian ini menunjukkan kompetensi inti dalam ketentuan kurikulum 2013 yaitu meliputi KI-1 sikap spiritual, KI-2 sikap sosial, KI-3 pengetahuan, KI-4 keterampilan.

Kompetensi Dasar dan Indikator Pencapaian Kompetensi

Bagian KD menunjukkan kompetensi dalam kurikulum yang harus dicapai peserta didik pada materi tertentu. Sedangkan indikator merupakan penjabaran khusus dari KD dengan menggunakan beberapa kata kerja operasional lainnya. Dalam penelitian ini, KD untuk materi sistem ekskresi manusia yaitu KD 3.10 menganalisis sistem ekskresi pada manusia dan memahami gangguan pada sistem ekskresi serta upaya menjaga kesehatan sistem ekskresi. Sedangkan indikator terdiri dari 4 butir indikator yaitu: memecahkan konsep struktur dan fungsi organ-organ sistem ekskresi manusia, menyimpulkan proses pengeluaran zat sisa oleh organorgan sistem ekskresi manusia, mengidentifikasi gangguan sistem ekskresi manusia, dan menelaah upaya menjaga kesehatan sistem ekskresi manusia

Tujuan Pembelajaran

Bagian ini menunjukkan tujuan khusus yang lebih spesifik berupa poin-poin yang akan dicapai peserta didik setelah mengikuti proses pembelajaran yang mengacu pada indikator. Dalam penelitian ini, tujuan pembelajaran disusun berjumlah 16 tujuan pembelajaran dan disusun menggunakan unsur A (audience), B (behavior), C (condition), dan D (degree).

Materi Pembelajaran

Bagian ini menunjukkan pengetahuan fakta, konsep, prinsip, prosedur dan metakognitif yang relevan dan ditulis dalam bentuk butir-butir sesuai dengan rumusan indikator ketercapaian kompetensi. Dalam penelitian ini, butir-butir materi pembelajaran disusun berdasarkan pengetahuan fakta, pengetahuan konsep, pengetahuan prosedural, dan pengetahuan metakognitif pada materi sistem ekskresi manusia.

Metode Pembelajaran

Bagian ini menunjukkan cara yang digunakan oleh guru untuk mewujudkan suasana belajar dan proses pembelajaran agar peserta didik mencapai KD yang disesuaikan dengan karakteristik peserta didik. Dalam penelitian ini, metode yang digunakan yaitu presentasi dimana guru akan menjelaskan materi sistem ekskresi manusia kemudian metode selanjutnya yaitu diskusi dan permainan sehingga diskusi dibantu media teka-teki silang. 
Media Pembelajaran

Bagian ini berupa alat bantu proses pembelajaran yang digunakan guru agar lebih mudah dalam menyampaikan materi pelajaran. Dalam penelitian ini, media yang digunakan yaitu tekateki silang sistem ekskresi manusia.

Sumber Pelajar

Bagian ini dapat berupa buku, media cetak dan elektronik, alam sekitar, atau sumber belajar lain yang relevan. Dalam penelitian ini, sumber belajar yang digunakan yaitu buku IPA kelas VIII Semester Genap Kurikulum 2013 oleh Kemendikbud dan buku IPA lainnya yang menunjang.

Langkah-langkah Pembelajaran

Bagian ini dilakukan melalui tahapan pendahuluan, inti, dan penutup. Dalam penelitian ini, langkah pembelajaran dibuat dalam bentuk tabel yang berisi kegiatan pendahuluan, inti, dan penutup. Selain itu, dimasukkan juga sintaks atau langkah model pembelajaran kooperatif serta kegiatan guru dan kegiatan peserta didik.

Penilaian Hasil Belajar

Bagian ini menunjukkan penilaian untuk hasil belajar berdasarkan yang dilakukan oleh peserta didik selama proses pembelajaran dengan menggunakan instrumen penilaian. Dalam penelitian ini, aspek yang dinilai berupa kognitif melalui teknik tertulis sehingga peserta didik akan mengerjakan instrumen berupa soal tes pilihan ganda di akhir pembelajaran.

\section{Media Teka-Teki Silang (TTS)}

Pada jurnal Juwariyah (2015) dalam sejarahnya, teka-teki silang diterbitkan pertama kali oleh Arthur Wynne pada Tahun 1913 dalam majalah New York World yang menjadi fitur mingguan dalam majalah tersebut. Buku kumpulan TTS pertama kali terbit pada Tahun 1924 oleh Simon dan Schuster dan buku tersebut menjadi popular pada tahun tahun 1924. Puzzle adalah permainan konstruksi melalui kegiatan memasang atau menjodohkan kotak-kotak, atau bangun-bangun tertentu sehingga akhirnya membentuk sebuah pola tertentu (Rokhmat, 2006). Teka-teki silang merupakan puzzle yang berupa pertanyaan-pertanyaan yang harus dijawab dengan cara memasukan jawaban (huruf atau angka) tersebut ke dalam kotak-kotak yang tersedia baik secara horizontal maupun vertikal. Media pembelajaran crosswords puzzle merupakan permainan mengasah otak melalui pencarian dan pengingatan kata yang pas untuk jawaban pada kotak yang tersedia (Cahyo dalam Ermaita dkk, 2016).

Media pembelajaran adalah segala alat fisik yang dapat memperjelas penyajian pesan yang disampaikan oleh guru kepada peserta didik serta mambantu merangsang peserta didik untuk belajar. Pembelajaran yang difasilitasi dengan media berupa permainan TTS (Teka-Teki Silang) dapat meningkatkan motivasi siswa dalam belajar, mengurangi tekanan belajar, dan mampu menciptakan suasana yang menyenangkan (Sugiharti, 2013). Penelitian ini menggunakan media teka-teki silang yang telah dibuat oleh peneliti dan telah divalidasi oleh validator ahli, yaitu salah satu dosen Pendidikan Biologi di Universitas Bengkulu. Adapun cara pembuatan teka-teki silang menggunakan aplikasi Eclipse Crossword, yaitu buka software Eclipse Crossword Puzzle Creation, lalu pilih "I would like to start a new crossword" kemudian pilih "Next" untuk memulai pembuatan teka-teki silang. Kemudian tekan tombol "Next". Pilihlah "Let me create a word list from scratch no", kemudian pilih "Next". Langkah berikutnya, masukkan jawaban pada kotak di bawah tulisan "Word" dan soal pada kotak di bawah tulisan "Clue for this word". Pilih "Add to list" lakukan terus menerus sampai soal dan jawaban telah ditulis semua. Jika merasa yakin telah selesai mengisikan tekan tombol "Next". Maka akan muncul "Do you want to save this word list for the future use before continuing ?" pilih "Yes" kemudian pilihlah tempat menyimpan file tersebut. Pada tahap ini, kita boleh menuliskan nama file dan pembuat file atau jika tidak langsung pilih "Next". Tentukan banyak kotak yang akan dipergunakan. Ketik jumlah kotak kemudian tekan "Next". Tekateki silang telah jadi. Untuk menyimpan pilih "Save crossword", sedangkan untuk mencetak pilih "Print crossword" (Triyanto, 2013). 
Setelah teka-teki silang telah jadi, selanjutnya peneliti mendesain media dengan memberikan warna pada aplikasi dan menambahkan gambar menggunakan aplikasi Paint agar lebih menarik perhatian peserta didik. Dalam penelitian ini, media teka-teki silang digunakan agar menjadi sarana menarik untuk belajar karena rasa puas yang dirasakan peserta didik yang mampu memecahkan permasalahan, diharapkan peserta didik lebih tertarik dan termotivasi untuk belajar karena tidak menjadi bosan dibanding hanya mendengarkan materi guru dan berdiskusi kelompok saja, dapat membantu peserta didik untuk lebih memahami dan mengingat istilah-istilah ilmiah dalam pembelajaran IPA terutama materi sistem ekskresi manusia yang digunakan dalam penelitian ini. Penggunaan media ini sangat mudah dan media teka-teki silang sangatlah populer dalam dunia anak-anak sehingga guru tidak perlu lagi banyak menjelaskan penggunaan media ini kepada peserta didik (Amalia, 2018). Hal tersebut sesuai dengan pernyataan Cahyo dalam Jurnal Ermaita, dkk (2016) yang menjelaskan media pembelajaran teka-teki silang merupakan permainan mengasah otak melalui pencarian dan pengingatan kata yang pas untuk jawaban pada kotak yang tersedia. Teka-teki silang merupakan salah satu media pembelajaran menyenangkan dalam bentuk permainan yang dapat diterapkan dalam kegiatan pembelajaran. Teka-teki silang adalah suatu permainan teka-teki silang yang berguna untuk mempelajari pola pikir, pemikiran logis, sistem pendekatan, serta pemecahan masalah secara umum. Media teka-teki silang tersebut berisikan pertanyaan-pertanyaan mengenai sistem ekskresi manusia yang digunakan untuk 4 kali pertemuan.

Pada pertemuan pertama, peserta didik diminta untuk mengisi pertanyaan-pertanyaan mengenai materi ginjal yang terdiri dari struktur dan fungsi ginjal, proses pengeluaran zat sisa oleh ginjal, dan gangguan pada ginjal. Susunan pertanyaan dalam media teka-teki silang materi ginjal untuk pertemuan ke 1 terdiri dari 25 pertanyaan, 13 pertanyaan mendatar dan 12 pertanyaan menurun. Pada pertemuan kedua peserta didik diminta untuk mengisi pertanyaan-pertanyaan mengenai materi kulit yang terdiri dari struktur dan fungsi kulit, proses pengeluaran zat sisa oleh kulit, dan gangguan pada kulit. Susunan pertanyaan dalam media teka-teki silang untuk pertemuan ke 2 terdiri dari 20 pertanyaan, 11 pertanyaan mendatar dan 9 pertanyaan menurun. Pada pertemuan ketiga peserta didik diminta untuk mengisi pertanyaan-pertanyaan mengenai materi hati yang terdiri dari struktur dan fungsi hati, proses pengeluaran zat sisa oleh hati, dan gangguan pada hati. Susunan pertanyaan dalam media teka-teki silang materi hati untuk pertemuan ke 3 terdiri dari 20 pertanyaan, 12 pertanyaan mendatar dan 8 pertanyaan menurun. Pada pertemuan keempat peserta didik diminta untuk mengisi pertanyaan-pertanyaan mengenai materi paru-paru yang terdiri dari struktur dan fungsi paru-paru, proses pengeluaran zat sisa oleh paru-paru, dan gangguan pada paruparu. Susunan pertanyaan dalam media teka-teki silang materi paru-paru untuk pertemuan ke 4 terdiri dari 20 pertanyaan, 11 pertanyaan mendatar dan 9 pertanyaan menurun.

Dalam penelitian ini, media teka-teki silang dirancang dengan format sebagai berikut: (1) Halaman depan (cover) media TTS yang memuat judul teka-teki silang, kelas/semester peserta didik, identitas penulis, dan identitas lembaga penulis yang dapat dilihat pada Gambar 1. (2) Lembar identitas peserta didik, memuat nama, kelas, dan kelompok peserta didik yang dapat dilihat pada Gambar 2. (3) Lembar pengantar dan tujuan pembelajaran yang memuat sedikit gambaran mengenai media teka-teki silang tersebut, tujuan pembelajaran, dan tujuan kegiatan yang dapat dilihat pada Gambar 3. (4) Lembar landasan teori dan aturan permainan media TTS, memuat secara singkat teori sistem ekskresi manusia dan aturan permainan media teka-teki silang yang dapat dilihat pada Gambar 4. (5) Lembar pertanyaan yang memuat pertanyaan-pertanyaan mengenai sistem ekskresi manusia secara mendatar maupun menurun yang dapat dilihat pada Gambar 5. (6)Lembar jawaban, memuat kotak-kotak secara mendatar dan menurun untuk menjawab pertanyaan dengan cara mengisi jawaban ke dalam kotak-kotak yang telah diberikan yang dapat dilihat pada Gambar 6.

Berdasarkan hasil penelitian yang telah dilakukan bahwa menggunakan media pembelajaran dapat membantu guru dalam menyampaikan materi sehingga memudahkan guru untuk mencapai tujuan pembelajaran yang diinginkan. Hal tersebut sesuai dengan pernyataan Winataputra dalam Rahmanelli (2008) yang mengemukakan pembelajaran pembelajaran akan lebih efektif dan menarik 
bagi anak apabila dalam pelaksanaannya guru menggunakan media. Salah satu fungsi utama media pembelajaran adalah sebagai alat bantu mengajar yang turut mempengaruhi iklim, kondisi, dan lingkungan belajar yang ditata dan diciptakan oleh guru (Winarni, 2018).

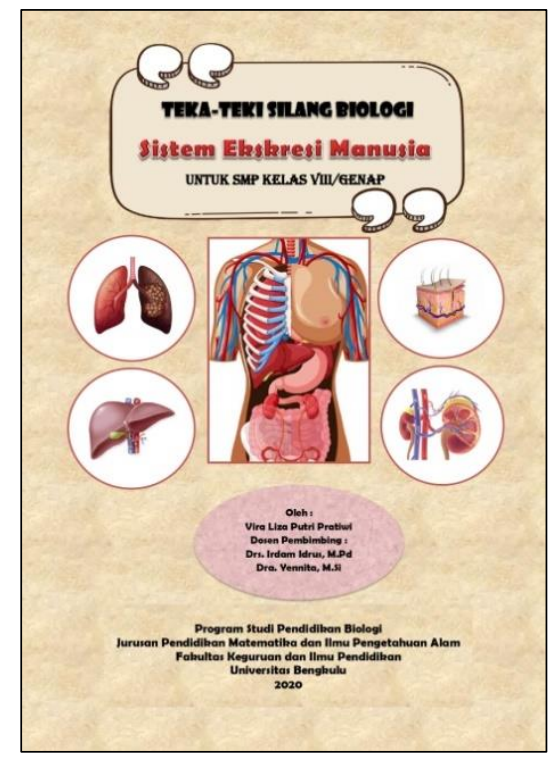

Gambar 1. Halaman Depan (cover) Media TTS

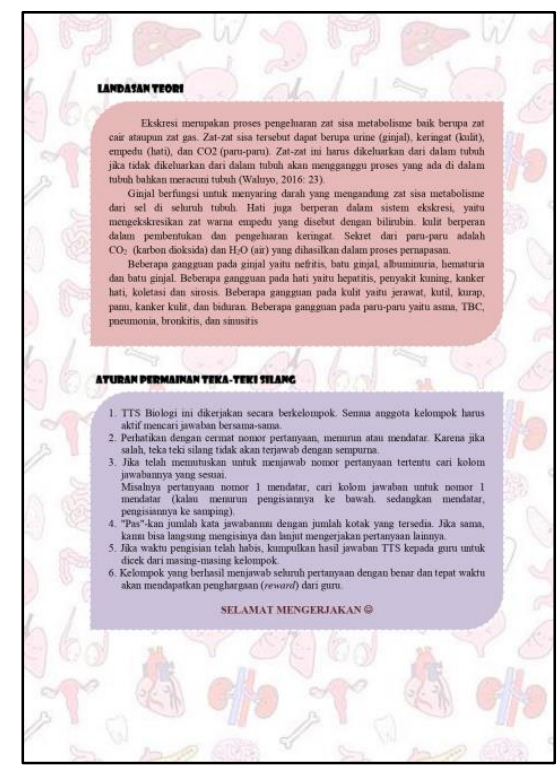

Gambar 4. Lembar Landasan Teori dan Aturan Permainan

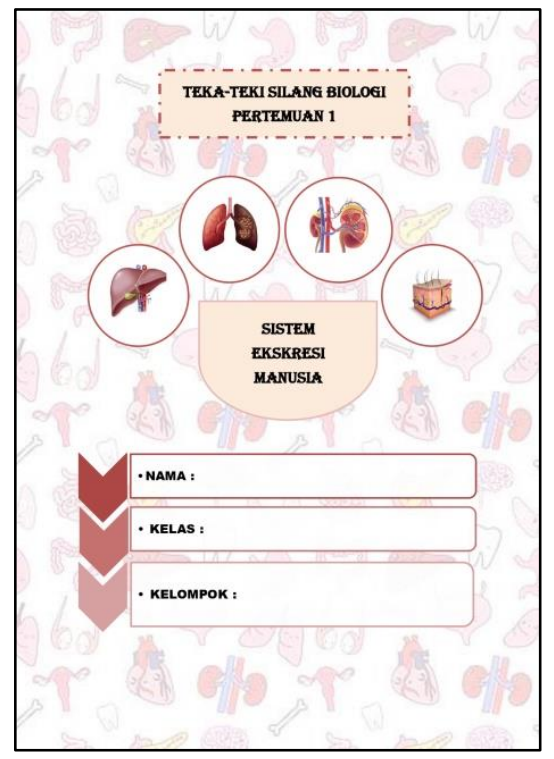

Gambar 2. Lembar Identitas Peserta Didik

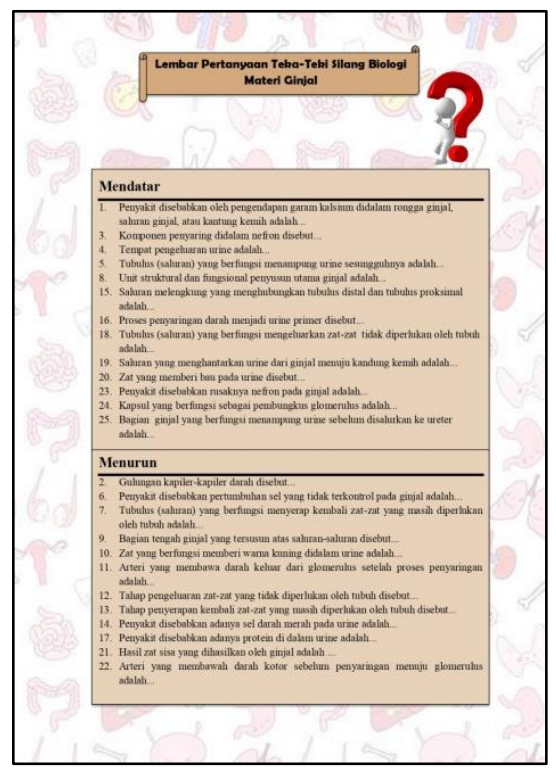

Gambar 5. Lembar Pertanyaan

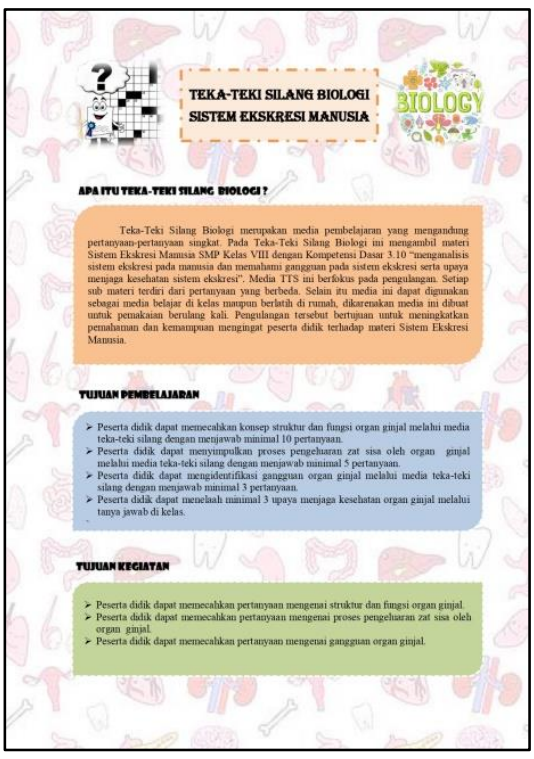

Gambar 3. Lembar Pengantar dan Tujuan Pembelajaran

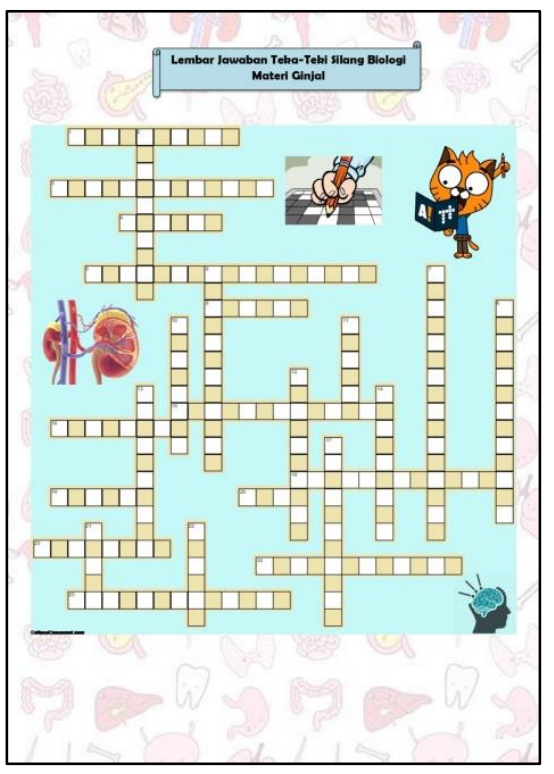

Gambar 6. Lembar Jawaban

\section{KESIMPULAN}

Berdasarkan hasil penelitian maka dapat disimpulkan bahwa perangkat pembelajaran yang dirancang berupa RPP yang telah dirancang sesuai dengan Permendikbud No. 22 Tahun 2016 untuk kelas VIII dengan alokasi waktu 10 JP (4 kali pertemuan). Selanjutnya media teka-teki silang yang dirancang untuk 4 kali pertemuan. Peserta didik secara berkelompok mengisi kotak-kotak jawaban secara mendatar dan menurun mengenai sistem ekskresi manusia, sesuai dengan pertanyaan yang telah diberikan. Media teka-teki silang disusun dengan format halaman depan, lembar identitas peserta didik, lembar pengantar dan tujuan pembelajaran, lembar landasan teori dan aturan permainan, lembar pertanyaan serta lembar jawaban. Harapannya di kemudian hari ada penelitian lanjutan agar rancangan perangkat pembelajaran yang telah dibuat peneliti dapat 
diperbaiki kekurangannya dan dapat diterapkan kepada peserta didik di sekolah.

\section{DAFTAR PUSTAKA}

Amalia, Nur H., \& Hidayat, Nur. (2018). Penggunaan Media Teka-Teki Silang (Crossword Puzzle) dalam Meningkatkan Kemampuan Baca Tulis Kosakata Bahasa Arab Peserta Didik Kelas III MI Ma'arif Giriloyo 1 Bantul. Al-Bidayah, 10(1). doi:10.14421/al-bidayah.v10i1.133.

Depdiknas. (2003). Undang-undang RI No.20 tahun 2003 Tentang Sistem Pendidikan Nasional. Jakarta: Depdiknas.

Ermaita., Pargito., \& Pujiati. (2016). Penggunaan Media Pembelajaran Crossword Puzzle Untuk Meningkatkan Keterampilan Berfikir Kreatif Siswa. Jurnal Studi Sosial, 4(1).

Furchan, Ahmad. (2004). Pengantar Penelitian dalam Pendidikan. Yogyakarta: Pustaka Pelajar Offset.

Juwariyah. (2015). Teka-Teki Silang (Crossword Puzzle) Dalam Pengajaran Mufrodat Bahasa Arab. Jurnal Pendidikan Bahasa Arab, 5(1). doi.org/10.14421/almahara.2015.011-07.

Kemendikbud. (2016). Permendikbud Nomor 22 Tahun 2016 Tentang Standar Proses Pendidikan Dan Menengah. Jakarta: Kemendikbud.

Kemendikbud. (2018). Permendikbud Nomor 35 Tahun 2018 Tentang Perubahan Atas Peraturan Menteri Pendidikan dan Kebudayaan Nomor 58 Tahun 2014 Tentang Kurikulum 2013 Sekolah Menengah Pertama/Madrasah Tsanawiyah. Jakarta: Kemendikbud.

Kemendikbud. (2018). Permendikbud Nomor 37 Tahun 2018 Tentang Perubahan Atas Peraturan Menteri Pendidikan dan Kebudayaan Nomor 24 Tahun 2016 Tentang Kompetensi Inti dan Kompetensi Dasar Pelajaran Pada Kurikulum 2013 Pada Pendidikan Dasar dan Pendidikan Menengah. Jakarta: Kemendikbud.

Lestari, T., Susanti, R., \& Santri, D. J. (2019). Pengaruh Model Pembelajaran Kooperatif Think Pair Share Dengan Bantuan Teka-Teki Silang Terhadap Hasil Belajar Peserta Didik Kelas VII SMP Negeri 45 Palembang Pada Materi Sistem Organisasi Kehidupan (Doctoral Dissertation, Sriwijaya University). Retrieved from https://repository.unsri.ac.id/914/.

Lubis, Hisnuddin. (2018). Peningkatan Pemahaman Konsep Dasar Sosiologi melalui Media Pembelajaran Teka Teki Silang Sosiologi. Hermeneutika, 4(2). doi:10.30870/hermeneutika.v4i2. 4830.

Mulyasa. (2007). Standar Kompetensi dan Sertifikasi Guru. Bandung: PT. Remaja Rosdakarya.

Nadimah, Nuha Arie., \& Raharjo, R. (2018). Pengembangan Media Teka-Teki Silang Untuk Meningkatkan Kemampuan Mengingat Siswa Kelas X SMA Pada Materi Fungi. BioEdu, 7(2), 433-440.

Pillai JA., Hall CB., Dickson., Dennis W., Lipton RB., \& Verghese J. (2011). Association Of Crossword Puzzle Participation With Memory Decline in Persons Who Develop Dementia. Journal Of The International Neuropsychological Society, 17(6). doi: 10.1017/S1355617711001111. 
Prasetyo, Zuhdan K., \& Siti Fatonah. (2011). Pengembangan Perangkat Pembelajaran Sains Terpadu Untuk Meningkatkan Kognitif, Keterampilan Proses, Kreativitas, serta Menerapkan Konsep Ilmiah Peserta Didik SMP. Yogyakarta: UNY.

Rahmanelli. (2008). Efektivitas Pemberian Tugas Media Puzzle dalam Pembelajaran Geografi Regional. Jurnal Pelangi Pendidikan, 30(1), 23-31.

Rokhmat, Joni. (2006). Pengembangan Taman Edukatif Berbasis Permainan untuk Permainan di TK dan SD. Jurnal Dinamika Pendidikan, 2(1), 59-67.

Rusman. (2012). Model-model Pembelajaran: Mengembangkan Profesionalisme Guru. Jakarta: Raja Grafindo Persada.

Stansfield W.D. (2014). Using Crossword Puzzles to Enhance Student's Learning of Technical Biological Terms. The American Biological Teacher. 76(6): 208-209.

Strauss, Anselm., \& Juliet Corbin. (2003). Dasar-dasar Penelitian Kualitatif. Yogyakarta: Pustaka Belajar.

Sugiharti, S. (2013). Studi Komparasi Penggunaan Media TTS dan LKS Pada Pembelajaran Kooperatif Student Teams Achievement Divisions (STAD) Pada Materi Pokok Sistem Periodik Unsur Kelas X Semester Gasal SMA Negeri 1 Karanganyar Tahun Pelajaran 2012/2013. Jurnal Pendidikan Kimia (JPK), 2 (1), 73-79.

Sutikno, Muhammad S. (2009). Belajar dan Pembelajaran. Bandung: Prospect.

Triyanto., \& Suhas Caryono. (2013). Rekomendasi Penggunaan Eclipse Crossword Puzzle Creation Pada Mata Pelajaran TIK Menurut Hasil Analisis Bimbingan Dan Konseling. Seminar Nasional Teknologi Dan Komunikasi. Yogyakarta, Indonesia. Retrieved from https://fti.uajy.ac.id/sentika /publikasi/makalah/2013/2013_21.pdf.

Winarni, Endang Widi. (2018). Pendekatan Ilmiah dalam Pembelajaran Inovatif dan Kreatif. Bengkulu: FKIP Universitas Bengkulu. 